\title{
ORGANISATIONAL NARCISSISM: A CASE OF FAILED CORPORATE GOVERNANCE?
}

\author{
Patricia Grant* \\ Faculty of Business \\ Auckland University of Technology \\ Te Wananga Aronui O Tamaki-Makau-Rau
}

Peter McGhee

Faculty of Business

Auckland University of Technology

Te Wananga Aronui O Tamaki-Makau-Rau

\begin{abstract}
Recent corporate scandals in New Zealand, evidenced by the collapse of two major unlisted finance companies, involved narcissistic leadership, which in turn, had created narcissistic organisational identities where unethical behaviour was the norm. This paper uses a virtue ethics approach to argue that the narcissistic tendencies found in some directors, senior managers and organisational cultures are largely determined at the corporate governance level of the organisation. The BOD is ultimately responsible for the moral or immoral identity of the organisation. However, instead of advocating for rule-based reform, the authors contend that the problem lies with the character of the directors and the manner in which they exercise their judgement. An emphasis on virtuous character and practical wisdom will encourage the development of a moral organisational identity and consequently improve individual ethical behaviour in organisations.
\end{abstract}

\section{* Author for correspondence:}

Patricia Grant

Email: Patricia.grant@aut.ac.nz

Tel: 099219999 ext 5212

Fax: 099219853 


\section{ORGANISATIONAL NARCISSISM: A CASE OF FAILED CORPORATE GOVERNANCE?}

\section{Introduction}

A developing body of literature has begun to explore the presence of narcissism in organisations and in organisational leaders (Chatterjee \& Hambrick, 2007; Downs, 1997 ; Duchon \& Drake, 2008; Roberts, 2001). Recent corporate scandals in New Zealand, evidenced by the collapse of two major unlisted finance companies, involved senior executives and directors promoting their organisations as the optimal choice for investors while misleading them, and then practicing denial when the company's serious financial problems became known. What kind of person would action such behaviour?

The authors contend these organisations' management control nexus (i.e. the board of directors (BOD), the chief executive officer (CEO) and the senior management (SM)) were narcissistic, and had, consequently, created narcissistic organisations where unethical behaviour was considered normal. Confronted with the challenge of improving ethical standards in general and avoiding narcissistic behaviour in particular, reformers could respond in one of two ways: to place more emphasis on character, or to change the rules of the institutions in which the individuals operate (Bragues, 2008). This paper argues that the narcissistic tendencies found in some directors, senior managers and organisational cultures are largely determined at the corporate governance level of the organisation. The BOD is ultimately responsible for the moral or immoral identity of the organisation. However, instead of advocating for rule reform, the authors contend that the problem lies with the character of the directors and the manner in which they exercise their judgement in the selection of the CEO and in-coming directors.

\section{The Vice of Narcissism}

In ancient mythology, Narcissus, a particularly handsome young man, rejects the advances of Echo a river nymph. A heartbroken Echo prays to Nemesis, the goddess of divine retribution against the proud, who causes Narcissus to fall in love with his reflection in a pool one day without grasping that the face gazing back at him is his own. Eventually, after pinning for some time, Narcissus recognizes the image in the water and realizing his inability to act upon this love, he wastes away to death at the edge of the pool (alternative versions of this tale have him reaching out to kiss his reflection and drowning or committing suicide by sword). 
According to the tale, his soul was sent to Hades, where he continues to gaze at his reflection in the river Styx, while the Narcissus flower grew where he died forever reaching towards the water.

The modern psychoanalytic genesis of the term narcissism is Sigmund's Freud's 1914 work On Narcissism: An Introduction. In this, Freud defines narcissism as "a state of being the centre of a loving world in which the individual could act spontaneously and purely out of desire” (A. D. Brown, 1997, p. 644). Freud believed that as infants we experienced this state and as adults we project the possibility of returning to such a state by means of our ego-ideal, that is, "our model of the person we must become in order for the world to love us as it did when we were young” (A. D. Brown, 1997, p. 644). Unfortunately, no individual can ever attain this ego-ideal. The resulting futile awareness of this search, and as a means to protect our sense of self, ensures certain ego-defence mechanisms occur. Central to this understanding of narcissism, is the need for individuals to maintain a positive sense of self and the engagement of ego-defensive actions to preserve self-esteem.

In modern parlance, yet still rooted in this ancient myth, narcissism "generally connotes a person who possesses an extreme love of the self, a grandiose sense of self-importance, and a powerful sense of entitlement” (Duchon \& Drake, 2008, p. 303). While useful, this definition needs further unpacking. Brown (1997), while noting the divergent conceptions of narcissism, summarised much of the extant literature into six broad behavioural/psychological characteristics. Denial, the first of these, has the narcissistic individual "disclaiming awareness, knowledge, or responsibility for faults that might otherwise attach to them” (p. 646). Rationalisation is the narcissist's attempt at justifying unacceptable behaviours or attitudes and presenting them in a socially acceptable form. Selfaggrandisement refers to the tendency to overestimate one's abilities or achievements. The narcissistic personality, imbued with these beliefs, is often accompanied by "extreme selfabsorption, a tendency toward exhibitionism, claims to uniqueness, and a sense of invulnerability” (p. 646). In addition to these characteristics, and to further self-enhancement, the narcissist also distorts reality through selective perception. This fourth one, attributional egotism, is the tendency to explain events in a self-serving manner and to attribute positive outcomes to causes internal to the self and negative outcomes to external factors. The psychoanalytic literature generally accepts that narcissists use self-serving behaviour to preserve and/or enhance self-esteem. A narcissist bolstered by the above characteristics, also 
has a strong sense of entitlement. This, in turn, is associated with "a strong belief in his/her right to exploit others and an inability to empathize with the feelings of others” (p. 647). Unfortunately, for him or her, this lack of feelings towards others matches an insatiable need for their approval and admiration. Thus, the narcissist finds themselves in the not-soenviable position of "holding in contempt and perhaps feeling threatened by the very individuals upon whom he or she is dependent for positive regard and affirmation" (p. 647). Finally, narcissism is also associated with high levels of anxiety. Research demonstrates that narcissists suffer from feelings of dejection, worthlessness, hypochondria, despair, emptiness, fragility, and hypersensitivity. While anxiety itself is not an ego-defence, it is what the above ego-defence mechanisms seek to ameliorate. ${ }^{1}$

According to Brown (1997), while these characteristics define narcissism in broad terms, narcissism also occurs on a continuum from "normal" or "healthy" at one end to "pathological " at the other. It is important to recognise that narcissism per se is a normal phenomenon and a "universal and healthy attribute of personality" (Cooper, 1986, p. 115) which represents a "healthy concern with the self and with self-esteem regulation" (Frosh, 1991, p. 75). However, when taken to the extreme, narcissism can constitute a disorder that inhibits an individual's capacity to function normally or to form meaningful relationships.

\section{Virtue Ethics and Corporate Governance}

Our discussion of Virtue Theory is based on the writings of Aristotle (and Alasdair MacIntyre to a lesser degree). Our focus is on the creation of a narcissistic organisational identity stemming from the personalities of senior figures. Sison (2008) has developed a corporate governance model based on Virtue Theory, arguing that good governance requires governors of good character. His model is based on Aristotle's understanding of governance as 'praxis' or action, as opposed to 'poiesis' or production. An 'action' is good if it leads the actor to grow in virtue, while 'production' is simply good if it is efficient.

\footnotetext{
${ }^{1}$ The American Psychiatric Association (APA) also lists narcissism among its personality disorders. The APA's Diagnostic \& Statistic Manual IV (DSM-IV) characterises a narcissistic individual as demonstrating several selfcentred attitudes and behaviours including exaggerating achievements, demanding of praise and admiration, a preoccupation with fantasises involving unlimited success, power, love and beauty, a feeling of superiority over others and of being more deserving based on that superiority, and being arrogant, haughty, patronising, or contemptuous.
} 
Before explaining further the implications this model has for narcissistic organisations, some important Aristotelian concepts need further explanation. Firstly, Aristotle provided an account of what it meant to have a successful life and a successful society (Flynn, 2008). For Aristotle, a successful or happy life or 'eudaimonia', is something everyone wants (Blackburn \& McGhee, 2007). By eudaimonia, Aristotle meant a life in which our human capabilities are put to their best use (Flynn, 2008). This is a life lived kat' areten, that is, a life lived in accordance with virtue. Aristotle arrives at his notion of virtue in the following way: when we say something performs well we mean it is fulfilling its purpose and the act or performance is 'good'; if the purpose of the human being consists in the exercise of our cognitive capacities then virtue is nothing more than reason excellently used (Bragues, 2006).

Neo-Aristotelians have unpacked these concepts further. Human nature contains a set of natural principles of practical reason, and when a person uses their practical reason (i.e. turns their mind to action), they open themselves to understand that in general, good should be done and evil avoided, and that virtue is good (Rhonheimer, 2008). In other words, human nature itself provides ethical goals (Annas, 1993). This is the basis for Aristotle's conclusion that a virtuous life is indeed a good life.

One's character is a result one's virtues. The virtues of character (moral virtues) such as courage and self-control arise through a repetition of action. They are habits engendered through practice but the practice of acquiring virtue always involves a rational choice; the choice endorses the habit. Flynn (2008) asserts that practical wisdom (prudence) is the virtue that guides reason in this choice and it grows as one develops in virtue.

Practical wisdom (prudence)...is a bridge between the intellectual and moral virtues. It entails an appreciation of the difference between what is good and bad in order to live a worthwhile life, and necessitates virtue of character in the sense that it cannot function properly without correct habits (p. 364).

Many other approaches to corporate governance consider governance as an activity belonging to the category of 'poiesis' or production (Sison, 2008). This possibly explains the emphasis placed on rules in many corporate governance regimes. It seems that globally, the ideal goal of governance theory, is to create a foolproof instruction manual on the task of good governance (Sison, 2008). However, according to Virtue Theory, the ideal governor would be a prudent one, exercising judgement rather than following rules. The excellence of 'praxis' is 
prudence which develops through the acquisition of all the virtues. Based on this model, the development of a moral organisational identity, as opposed to a narcissistic one, is more likely.

Virtue Theory also holds that a person's character not only influences their actions but also their perception. The virtue of prudence or practical wisdom is the ability to know specifically what is good to do here and now and we develop prudence by acquiring virtue.

As Aristotle wrote:

The wise do not see things in the same way as those who look for personal advantage. The practically wise are those who understand what is truly worthwhile, truly important, and thereby truly advantageous in life: who know in short, that is worthwhile to be virtuous (Aristotle, Trans. 1941; Book 6, Chp 13, 1144b31).

\section{Virtue and Organisational Identity}

Organisations, like individuals, have identities. ${ }^{2}$ These identities can be moral or immoral just as those of individuals. We argue that an organisation has a moral identity when it is centrally oriented towards a collection of virtues that both define what one is and what one tends to do. Morality is a function of an entity's character (MacIntyre, 2007) and "unless virtue is a central part of the organisation's self concept, ethical behaviour will never be considered an appropriate metric or standard to judge the outcome of decisions" (Duchon \& Drake 2008 p. 303)

In order to assess the development of the narcissistic organisation, let us consider how organisational identities form and function. Whetten (2006) defines organisational identity as "the central and enduring attributes of an organisation that distinguish it from other

\footnotetext{
${ }^{2}$ Whetten (2006) conception of organizational identity rests on two key assumptions taken from organization and identity theory:

1. Organizations are more than social collectives in that modern society treats organizations in many respects as if they were individuals - granting them analogous powers to act and assigning them analogous responsibilities as collective social actors

2. Identity is equated with an actor's subjective sense of uniqueness, referred to as the self-view or selfdefinition and reflected in notions such as self-governance and self-actualisation. Framed in this manner, the identity of individuals and organizations is an unobservable subjective state - a causal attribution that is inferred from its posited effects or consequences (p. 221).
} 
organisations" (p. 220). He refers to these as organisational identity claims. These legitimise an organisation's uniqueness and their capacity to determine a competitive domain and function ideally within that domain. These claims take two forms. Functionally, they consist of organisational attributes that determine similarity and difference from all others (i.e. this is who we are). Invoked consistently in organisational discourse, these attributes, refer to specific social categories (e.g., we are a university not a technical institution). This, in turn, signifies the boundaries of appropriate behaviour for a particular organisation. Structurally, organisational identity consists of attributes that configure activity in the organisation as shown in its programmes, policies and procedures, and that reflect its most important values. These attributes, invoked in organisational discourse as decision guides and points of communication, provide a foundation for the organisation in its all of its dealings (i.e., this is what we do; this is how we do it). When functional and structural attributes operate as irreversible commitments on some basis (i.e., they have passed the test of time; they have gained critical mass) they can "partially or completely eclipse the reference point that prevails more broadly external to the organisation” (Duchon \& Drake, 2008, p. 301). In other words, the identity of the organisation takes preference over reference points in other social groupings (e.g. family and society).

Organisations develop cultures that reinforce identity. A culture is "a set of important understandings that members of a community share in common” (Sathe, 1985, p. 6). These understandings are "largely tacit among members, are clearly relevant to particular groups, and are distinctive to the group” (Louis, 1985, p. 74). An organisation's culture displays central and enduring elements that make up its identity. These include such things as "customs and traditions, historical accounts be they mythical or accurate, tacit understandings, habits, norms and expectations, common meanings associated with fixed objects and established rites, shared assumptions, and intersubjective meanings" (Sergiovanni \& Corbally, 1984, p. viii). A culture embodies these elements and acts as a transferring mechanism of the organisation's identity to new members as the correct way to perceive, think and feel (Schein, 1992).

Individuals in organisations share a common social identification and organisational selfesteem is the collective self-esteem of the individuals acting as the organisation. Duchon \& Drake (2008) contend that organisations, as social entities, “exist in their members' common awareness of their membership, and so come to take on identities that are parts of their 
members' identities, needs, and behaviours” (p. 302). Consequently, when individuals strive to protect or enhance a self-concept derived from a particular social entity, they collectively modify the self-esteem of that entity. Hence, the organisation can regulate self-esteem with ego-defensive behaviours. These, in turn, protect identity and enhance the legitimacy of the organisation. Unfortunately, if organisations are motivated, like people, to "protect their collective identity and legitimacy, then like people, they too can sometimes engage in extreme narcissistic behaviour" (p. 303).

\section{Organisational Narcissism}

As discussed earlier, the psychoanalytic literature generally views narcissistic behaviours as ego-defence mechanisms used to bolster an individual's self-concept and protect their identity. Organisations, as collective entities of individuals, are similar. They also have needs for self-esteem that are regulated narcissistically (A. D. Brown, 1997). This response is a coping mechanism intended to protect and preserve the organisation's identity. Unfortunately, like individuals, organisational ego-defence mechanisms taken to the extreme can lead to dysfunction and/or ruin. Furthermore, in the effort to protect itself, an organisation may create structures that reinforce and extend an extreme narcissistic identity. The extreme narcissistic organisation "loses sight of the 'reality' of its position in the marketplace and employs denial, self-aggrandizement, and a sense of entitlement to prop up its damaged sense of identity" (Duchon \& Burns, 2008, p. 355). Such an entity seeks legitimacy at the expense of accountability. They pay scant attention to market responsibility, civic duty or ethical concerns (Ganesh, 2003). Consequently, the extreme narcissistic organisation is recognisable by observable attributes and behaviours.

According to Brown (1997), such organisations deny facts about themselves using spokespeople, propaganda campaigns, annual reports and myths. They develop justifications for their actions through rationalisation. They self-aggrandise by making claims to their uniqueness, commissioning corporate histories and deploying their office layouts and architecture as signs of status, prestige and vanity. Narcissistic organisations, states Brown, attribute failure of their decisions to external factors, while at the same time, attributing positive results to the organisation itself. Annual reports, publicity campaigns and the manipulation of the media are among the variety of means utilised to achieve this purpose. Such organisations also assume an entitlement to continued successful existence and a consequent entitlement to exploit resources, people and other organisations to achieve this 
continued success. Finally, the narcissistic organisation suffers from social instability and alienation.

There are several real-life examples in the research literature that correspond with Brown's (1997) criteria. Stein (2003), in his investigation of the near collapse of the highly prestigious hedge-fund Long term Capital Management (LTCM) in 1998, found that acute narcissism in this organisation mirrored Brown's (1997) description. Stein contends that an exaggerated sense of pride and conception of power and knowledge led the directors of LTCM to take unnecessary and extreme risks in the financial markets. Secondly, the feelings of contempt that LTCM had for others in the market - and a desire to demonstrate their superiority by triumphing over them - led the directors to increase their risk substantially. Ketola (2006) analysing the psychological defences of a company dealing with an oil spill identified the ego-defence mechanisms used to protect organisational identity, even at the expense of its morality. When faced with accusations of misconduct, the organisation practiced denial, repression, omnipotence, and attributional sublimation to avoid having to deal with the facts of their own actions. When confronted with the reality of the spill, they used rationalisation to accept responsibility but devalued the harmful impact of the spill on others and the environment.

Acute narcissistic organisations' identity and culture are excessively self-centred and exploitative. Duchon \& Drake (2008) contend that

Their membership will obsessively employ a sense of entitlement, selfaggrandizement, denial and rationalizations to justify their behaviour and so protect the collective identity. Such organisations are not intentionally unethical - they are likely to have formal ethics programmes - but concerns about ethical, or even legal behavior will receive little more than lip service (p. 305)

Ethics programmes in narcissistic organisations are a form of self-preservation - they are a way of telling the world 'everything is good here'. Furthermore, Roberts (2001) contends, that such programmes are window dressing; what is relevant is not whether the ethics programme is in use but only that a narcissistic organisation appears to be implementing it. This allows the operational interior free to carry out its usual practices. 
The management-control nexus is often a source and perpetuator of organisational narcissism. Research has highlighted the strong relationship between leadership and an organisation's identity (Curry, 2002; Voss, Cable, \& Voss, 2006; Walsh \& Glynn, 2008) and culture (Schein, 1992; Taormina, 2008; Toor \& Ofori, 2009). Leaders embody and enact identity through discourse and policy/procedure setting. Consequently, they become the focal point of decision-making in the organisation. At the same time, their behaviours encourage the development of norms that inform employees throughout the organisation in a set of particular actions.

If the organisational leadership is extremely narcissistic, then it is probable that identity and culture will mirror leadership and individuals within the organisation will reflect narcissistic tendencies. Once these practices become institutionalised, it is probable that individuals will think of their organisation, and themselves, as moral and continue their narcissistic (and likely unethical) behaviour without guilt (Anand, Ashworth, \& Joshi, 2005). To those on the outside, this seems perverse, but those who have internalised the organisation's culture see nothing wrong in what they are doing. To question what the organisation is doing is to threaten collective, and ultimately, individual identities' that operate within it. As Duchon \& Drake (2008) note, "extreme narcissistic organisations cannot behave properly because they do not have a moral identity” (p. 306).

Duchon \& Burns (2008) categorized Enron as having an extreme narcissistic identity. They quote Kurt Eichenwald's book Conspiracy of Fools

Crime was just one ingredient in a toxic stew of shocking incompetence, unjustified arrogance, compromised ethics, and an utter contempt for the market's judgement. Ultimately, it was Enron's tragedy to be filled with people smart enough to know how to manoeuvre around the rules, but not wise enough to understand why the rules had been written in the first place (p. 358).

Duchon \& Burns contend people in Enron were unwise because they operated in an extremely narcissistic environment characterised by entitlement, self-aggrandizement and denial that anything was out of order. The management-control nexus at Enron believed they were entitled to success. This led them to skirt around the rules applicable to everyone else. For example, they created and used their own projections for income as opposed to markettrading prices. They avoided conventional accounting practices whenever it wanted to. Leadership believed they were entitled to a healthy-looking balance sheet. Enron viewed 
itself as omnipotent, changing the world for the better in a Godlike manner. The executives often spoke in messianic tones and viewed themselves as the best of the best, which, in turn, resulted in excessive exhibitionism throughout the company. Finally, when everything came to its inevitable conclusion in 2002, Enron and its executives went into denial mode. While this was morally questionable, what was worse was that Enron had been ignoring evidence of fraud and insider trading for years. Indeed, this had become standard practice in the company desperate to protect its identity.

Something comparable happened at Hanover Finance \& Bridgecorp in New Zealand (albeit on a smaller scale). It appears there were similar narcissistic defence mechanisms at work in both these organisations. In Hanover's case, the management-control nexus were happy to skip around the market rules when it suited. For example, no consolidated accounts existed, there were large numbers of intercompany transactions of dubious nature and there was an extremely high ratio of related party transactions (Cone, 26 March, 2004). Independent directors were appointed late to the board, and right up until its insolvency, Hanover was still advertising itself as a finance company that could "handle any conditions even when its independent credit rating clearly is of a different view and the entire sector is operating in adverse conditions"(Gibson, June 20, 2010). Gaynor (21 Nov, 2009) notes, that Hanover Finance was one of the worst examples of corporate \& management governance in New Zealand's recent history. He also detailed questionable related party transactions while claiming that Hanover was partly a private bank for its executives. No one in the company questioned these practices and conflicts of interest. Indeed, they appeared of little concern to management.

Hanover constantly portrayed themselves as the biggest and the brightest of finance companies in New Zealand. They were more than happy to boast of their $\$ 1$ billion dollar worth, their worthy community work ${ }^{3}$ and, as Deborah Hill Cone acerbically noted, "they're not adverse to stories that make them look like big swinging dicks, such as when they were trying to put the kybosh on GPG's plans for Tower” (26 March, 2004). In appealing against a judgement that caused them to remove adverts promoting this image, Hanover replied that it was "strong \& capably managed by experienced people so that it can withstand any conditions and that Hanover Group had more than $\$ 1$ billion dollars of assets so it must be

\footnotetext{
${ }^{3}$ For example, saving the carnivorous Kauri snail in the Maungataniwha forest or their Stand Tall charity
} 
true” (Gibson, June 20, 2010). This self-aggrandizement led to exhibitionism both within the company and without. The founding director and CEO, Mark Hotchin, threw an elaborate birthday party for 80 guests at one of Fiji’s most expensive resorts and started building a \$30 million dollar residence while 17,000 investors were \$527 million dollars out of pocket perhaps exemplifies this best; images of Nero fiddling while Rome burns spring to mind.

Finally, when it all started going pear-shaped, Hanover, and its management-control nexus, did what all narcissistic organisations do. First, they denied anything was wrong, no surprise given that they had ignored many of these questionable practices up to that date. Second, they sought to shift the blame. Third, they provided guarantees to their investors about how they were going to fix it. To date the proposed $\$ 96$ million of Hotchin \& Watson's own money to prop up falling investors is still coming (McNabb, September 27, 2010).

Bridgecorp is a similarly sad story. When Bridgecorp collapsed, it owed 14,500 investors approximately $\$ 460$ million dollars. Again, the CEO, Rod Petricevic appeared to have treated the failed company as his own private bank. According to the Serious Fraud Office ${ }^{4}$, he gave $\$ 1.2$ million of Bridgecorp funds, to a business entity called $\mathrm{ABb}$, an unregistered company run by a personal friend of Petricevic and used $\$ 1.8$ million of investors' money to purchase and maintain the operational costs of a luxury yacht, the Medici (Nordqvist 28 June, 2010).

The evidence suggests that the management-control nexus of Bridgecorp had acted in a narcissistic manner. Again, we see a belief in the entitlement to success led management to make untrue statements in their investment statements and registered prospectus concerning the company's overall financial position, solvency and liquidity. There were also dubious related party transactions, lending policies and procedures, and disclosure statements (Marwick, 23 Dec, 2008). Again, we see the self-aggrandizement, the belief that "the normal rules do not apply here", and the idea that Bridgecorp is different or better than other companies. Finally, similar to our earlier examples, when the floodgates opened, the response was first one of denial then one of blame.

\footnotetext{
${ }^{4}$ The Government Department that detects, investigates and prosecutes cases of serious and complex fraud. Found at http://www.sfo.govt.nz/Serious Fraud Office.html
} 


\section{Moral Organisational Identity and Leadership}

It is this paper's contention that organisational narcissism, as demonstrated in the examples above, begins and ends with the management-control nexus and in particular the individual directors on the Board. This is because leaders shape the moral identity of the organisation. Weaver (2006) includes leader behaviour as a key determinant in the development of virtuous and vicious identities in organisations. This happens by members modelling leader behaviour (Bandura, 1986 ; M. E. Brown, Trevino, \& Harrison, 2005; G.R. Weaver, Treviño, \& Agle, 2005) and from the way organisational cultural norms undermining virtue are internalised (Treviño \& Weaver, 2003 ).

The wider leadership literature supports this causal link between leader behaviour and the moral identity of the organisation. Gini (2004) asserts that all leadership is ideologically driven and it is about passing on values so that the ethics of the leaders determines the ethics of the organisation. Andreoli \& Lefkowitz (2009) found that an ethical climate created by moral leadership was one of the most significant antecedents of ethical conduct. Others have emphasized the importance of consistency in communication and behaviour, in other words, 'leaders needing to walk the talk', and the resulting benefits in terms of effective role modelling and perceived integrity (Gini, 1997; Kouzes \& Posner, 1993; Oliverio, 1989; Simons, 1999).

Some authors have argued that leader role modelling is the most critical factor determining ethical culture (Dickson , Smith , Grojean , \& Ehrhart 2001 ; Morgan, 1993; Murphy \& Enderle, 1995; Nielsen, 1989; Schein, 1992; Sims \& Brinkmann, 2002). Jackall (1988) suggested that ethical behaviour in organisations is often reduced to adulating and imitating one's superiors. Lord and Brown (2001) claim that leaders provide a 'natural source of values' for their employees while Bandura (1977), in discussions of socialization and social learning theory, suggests that employees imitate the values stemming from their leaders. Hood (2003), who looked specifically at the relationship between the CEO's leadership style, values and the ethical practices of the organisation, found that leadership styles do influence ethical practices in the organisation. Brown, et al. (2005) considered managers to be a key source of guidance for ethical behaviour. 
Given this strong relationship between leadership and moral identity, we argue that if the management-control nexus exhibits narcissism, then it is probable that the individuals and the organisation as a whole will reflect these narcissistic tendencies.

So, what does a narcissistic organisation look like? Duchon and Drake (2008) have argued that an organisation's identity operates as an analogy to an individual's personality and essentially determines its moral behaviour. They even go so far as to claim that an extreme narcissistic organisation cannot behave properly because it does not have a moral identity. This is because the organisation's identity does not contain a predisposition to act virtuously and so it is morally flawed.

Narcissistic organisations use ego-defence mechanisms to protect the integrity of its personality even at the expense of sacrificing the morality of its actions (Ketola, 2006). They become self-obsessed and use a sense of entitlement, self-aggrandizement, denial, and rationalisations to justify anything they do (Duchon \& Drake, 2008). In such organisations, individuals and groups may be responsible for making decisions but those decisions will tend to be consistent with the larger system's moral identity (G. R. Weaver, 2006) and so unethical behaviour can emerge unintentionally. This may explain how in the above-mentioned cases individual decision makers in senior positions did not question blatantly unethical behaviour.

\section{Employing a Virtue Model for Leadership Appointments}

This paper argues that the board of directors (BOD) ultimately determines the moral identity of the organisation through its choice of the Chief Executive Officer (CEO) and incoming directors. The BOD selects and appoints the CEO, who in turn, selects their management team and together they set the tone of the organisation (Schwartz, Dunfee, \& Kline, 2005). While the law in New Zealand does not require a CEO and a management team (Institute of Directors 2008), the reality is that a BOD simply cannot manage a company requiring day-today attention. A CEO and executive team under the direction and supervision of a BOD manages the organisation. Consequently, the CEO is the main portal through which a BOD exercises its direction and supervision; and in the main, the CEO shapes and nourishes the 
organisation's identity. The selection of the CEO is therefore one of the most important decisions a BOD makes (IODNZ, 2008). ${ }^{5}$

Section 131 of the Companies Act in New Zealand requires directors to act in "good faith" and in what they believe to be the best interests of the company. While current business culture equates this with short-term monetary gain for a few (Pearlstein, 11 Sept, 2009), this culture could change. The Board of any company has the power to minimise the likelihood of organisational narcissism occurring by appointing directors and CEOs of "good" moral character, who also possess desired qualities such as business ability and ambition to maximise profits. However, the perception of what makes a 'good' director or CEO is a reflection of the moral character of each director on the Board, and the same can be said of the CEO in their selection of the senior management team. How do we know how a good CEO behaves?

The author's contend that Directors of 'good' character (in the Virtue Theory sense) would have a more holistic understanding of their responsibilities. Such a person will aim to achieve wealth in a virtuous way. They will not permit self-interest to take over- they will strive to be virtuous whether it benefits them or others (Annas, 2006). They will work for the long-term survival of the company as a whole in a virtuous manner. They will judge as a suitable candidate for director or CEO to be one who is committed to these goals. Furthermore, they will resist pressures to act in their own interests or sit back and let others pursue their selfinterest or jeopardise the future of the company by excessive risk-taking to bolster short-term results.

\section{Conclusion}

It is has been argued in this paper that the moral identity of an organisation is directly linked to the good character of individual directors on the Board. Prudent directors will ensure moral governance and the virtuous characters of the leaders of any organisation are the main determinants of the identity of that organisation. The sitting directors have the responsibility

\footnotetext{
${ }^{5}$ In New Zealand, the existing directors effectively chose new directors. Shareholders are passive and cede significant authority to existing directors in relation to the selection of new directors. Consequently, the board itself determines the culture of the board.
} 
of selecting the CEO and nominating suitable candidates for future directorships. There judgement as to the nature of a good governor is crucial. Only a director of good character would recognise that an ideal CEO or director would be one, who has a good character. The presence of such leaders would ensure the establishment and maintenance of a moral organisational identity. 
References

Anand, V., Ashworth, B. E., \& Joshi, M. (2005). Business as usual: The acceptance and perpetuation of coruption in orgnaizations. Academy of Management Executive, 1, 923.

Andreoli, N., \& Lefkowitz, J. (2009). Individual and organisational antecedents of misconduct in organisations. Journal of Business Ethics, 85 (309-332).

Annas, J. (1993). The morality of happiness. Oxford: Oxford University Press.

Annas, J. (2006). Virtue ethics. In D. Copp. (Ed.), The Oxford Handbook of Ethical Theory (pp. 515-536). Oxford: Oxford University Press.

Aristotle. (Trans. 1941). Nichomachean ethics. In R. McKeon (Ed.), The Basic Works of Aristotle. New York: Random House.

Bandura, A. (1977). Social Learning Theory. Englewood Cliffs, NJ: Prentice Hall.

Bandura, A. (1986 ). Social foundations of thought and action: A social cognitive theory. Englewood Cliffs, NJ: Prentice Hall.

Blackburn, M., \& McGhee, P. (2007). The excellent entrepreneur: Old virtues for new ventures? Australian Journal of Professional and Applied Ethics, 9(2), 46-55.

Bragues, G. (2006). Seek the good life, not money: The Aristotelian approach to business ethics. Journal of Business Ethics, 67(4), 341-357.

Bragues, G. (2008). The ancients against the moderns: Focusing on the character of corporate leaders. Journal of Business Ethics, 78(3), 373-392.

Brown, A. D. (1997). Narcissism, identity, and legitimacy. Academy of Management Review, 22(3), 643-686.

Brown, M. E., Trevino, L. K., \& Harrison, D. A. (2005). Ethical leadership: A social Learning perspective for construct development and testing. Organizational Behaviour and Human Decision Processes, 97(117-134).

Chatterjee, A., \& Hambrick, D. (2007). It's all about me: Narcissistic CEOs and their effects on company strategy and performance. Administrative Science Quarterly, 52(3), 351386.

Cone, D. H. (26 March, 2004). The secretive rise of the House of Hanover. New Zealand Herald. Retrieved from www.sharechat.co.nz/article/85411e2a/the-secretive-rise-ofthe-house-of-hanover 
Cooper, A. M. (1986). Narcissism. In A. Morrison (Ed.), Essential Papers on Narcissim (pp. 112-143). New York: New York University Press.

Curry, B. K. (2002). The influence of the leader persona on organizational identity. Journal of Leadership \& Organizational Studies, 8(4), 33-42.

Dickson , M. W., Smith , D. B., Grojean , M. W., \& Ehrhart , M. (2001 ). An organizational climate regarding ethics: The outcome of leader values and the practices that reflect them. Leadership Quarterly, 12197 - 217.

Downs, A. (1997 ). Beyond the looking glass: Overcoming the seductive culture of corporate narcissism. New York: AMACOM.

Duchon, D., \& Burns, M. (2008). Organizational narcissism. Organizational Dynamics, 37(4), 354-363.

Duchon, D., \& Drake, B. (2008). Organizational narcissism \& virtuous behavior. Journal of Business Ethics, 85, 301-308.

Flynn, G. (2008). The virtuous manager. Journal of Business Ethics, 78, 359-372.

Frosh, S. (1991). Identity crises, modernity, psychoanalysis and the self. Basingstoke, UK: Macmillan.

Ganesh, S. (2003). Organizational Narcissism Management Communication Quarterly, 16(4), 558-594.

Gaynor, B. (21 Nov, 2009). Open mind on Hanover-Allied proposal. New Zealand Herald.

Gibson, A. (June 20, 2010). Hanover loses appeal over 'size \& strength' ad. New Zealand Herald. Retrieved from www.nzherald.co.nz/news/printcfm?objectid=10517327

Gini, A. (1997). Moral leadership: An overview. Journal of Business Ethics 16(3), 323-331.

Gini, A. (2004). Business, ethics, and leadership in a post Enron era. Journal of Leadership \& Organizational Studies, 11(1), 9-16.

Hood, J. N. (2003). The relationship of leadership style and CEO values to ethical practices in organizations. Journal of Business Ethics, 43(4), 263-273.

IODNZ. (2008). Company success starts at the top. Retrieved from http://www.iod.org.nz/Home/Articles/Press_Releases/Company_success_starts_at_th e.aspx

Jackall, R. (1988). Moral mazes: The world of corporate managers. New York: Oxford University Press.

Ketola, T. (2006). Corporate psychological defences: An oil spill case. Journal of Business Ethics, 65, 149-161. 
Kouzes, J. M., \& Posner, B. Z. (1993). Credibility: How leaders gain and lose it and why people demand it. San Francisco: Jossey-Bass.

Lord, R., \& Brown, D. (2001). Leadership, values and subordinate self-concepts. The Leadership Quarterly, 12(133-152).

Louis, M. (1985). An investigators guide to workplace culture. In P. Frost, L. Moore, M. Louis, C. Lundberg \& J. Martin (Eds.), Organizational Culture (pp. 73-94). Beverly Hills, CA: Sage.

MacIntyre, A. (2007). After Virtue (3rd ed.). Notre Dame, IN: University of Notre Dame Press.

Martin, J. (2002). Organizational culture: Mapping the terrain. Thousand Oaks, CA: Sage Publications.

Marwick, R. (23 Dec, 2008). Bridegcorp chairman \& remaining directors charged. Retrieved from www.sec-com.govt.nz/new/releases/2008/2311208.shtml?print=true

McNabb, D. (September 27, 2010). Watson left sleeping with the enemy. New Zealand Herald. $\quad$ Retrieved from http://www.nzherald.co.nz/business/news/article.cfm?c_id=3\&objectid=10675803

Morgan, R. B. (1993). Self and co-worker perceptions of ethics and their relationships to leadership and salary. Academy of Management Journal, 36(200-215).

Murphy, P. E., \& Enderle, G., , (), . (1995). Managerial ethical leadership: Examples do matter. Business Ethics Quarterly, 5(1), 117-129.

Nielsen, R. P. (1989). Changing unethical organizational behaviour. The Academy of Management Executive, 3(2), 123-131.

Nordqvist, S. (28 June, 2010). Petricevic back in court amid Bridgecorp fraud claims. New Zealand Herald. $\quad$ Retrieved from http://www.nzherald.co.nz/business/news/article.cfm?c_id=3\&objectid=10654994

Oliverio, M. E. (1989). The implementation of a code of ethics: The early efforts,. Journal of Business Ethics, 8(5), 367-375.

Pearlstein, P. (11 Sept, 2009). Wall Street's Mania for Short-Term Results Hurts Economy. The Washington Post.

Rhonheimer, M. (2008). The perspective of the acting person: Essays in the renewal of Thomistic moral philosophy. Washington: Catholic University of America Press.

Roberts, J. (2001). Corporate governance and the ethics of narcissus Business Ethics Quarterly, 11(1), 109-127. 
Sathe, V. (1985). Culture and related coporate realities: Text, cases, and readings on organizational entry, establishment, and change. Homewood, ILL: Irwin.

Schein, E. (1992). Organizational Culture \& Leadership (2nd ed.). San Francisco: JosseyBass.

Schwartz, M., Dunfee, T., \& Kline, M. (2005). Tone at the top: An ethics code for directors? Journal of Business Ethics, 58, 79 -100.

Sergiovanni, T., \& Corbally, J. (1984). Leadership and organizational culture. Urbana: University of Illinois Press.

Simons, T. L. (1999). Behavioural integrity as a critical Ingredient for transformational Leadership. Journal of Organizational Change Management 12(2), 89-104.

Sims, R. R., \& Brinkmann, J. (2002). Leaders as moral role models: The case of John Gutfreund at Salomon Brothers. Journal of Business Ethics, 35(4), 327-340.

Sison, A. J. G. (2008). Corporate governance and ethics: An Aristotelian perspective. Cheltenham, UK: Edward Elger.

Stein, M. (2003). Unbounded irrationality: Risk and organizational narcissism at Long Term capital Management Human Relations, 56(5), 523-540.

Taormina, R. J. (2008). Interrelating leadership behaviors, organizational socialization, and organizational culture. Leadership \& Organization Development Journal, 29(1), 85102.

Toor, S., \& Ofori, G. (2009). Ethical leadership: Examining the relationships with full range leadership model, mmployee outcomes, and organizational Culture. Journal of Business Ethics, 90(4), 533-547.

Treviño, L. K., \& Weaver, G. R. (2003 ). Managing ethics in business organizations: Social scientific perspectives. Stanford, CA: Stanford University Press.

Voss, Z. D., Cable, D. M., \& Voss, G. B. (2006). Organizational identity and firm performance: What happens when leaders disagree about "who we are?". Organization Science, 17(6), 741-755,771-772.

Walsh, I., \& Glynn, M. (2008). The way we were: Legacy organizational identity and the role of leadership. Corporate Reputation Review: Special Issue: Organizational Identity, 11(3), 262-276.

Weaver, G. R. (2006). Virtue in organisations: Moral identity as a foundations for moral agency. Organisation Studies, 27(3), 341-368.

Weaver, G. R., Treviño, L., \& Agle, B. (2005). Somebody I look up to: Ethical role modelling in organizations. Organizational Dynamics, 34(4), 313-330. 
Whetten, D. A. (2006). Strengthening the concept of organizational idenity. Journal of Management Inquiry 15(3), 219-234. 